Published by the UFS

http://journals.ufs.ac.za/index.php/trp

(c) Creative Commons With Attribution (CC-BY)

How to cite: Hosea, P. \& Khalema, E. 2020 . Scoping the nexus between climate change and water-

security realities in rural South Africa. Town and Regional Planning, no.77, pp. 18-30.

\section{Scoping the nexus between climate change and water-security realities in rural South Africa}

\section{Patrick Hosea \& Ernest Khalema}

\section{DOI: http://dx.doi.org/10.18820/2415-0495/trp77i1.2}

Peer reviewed and revised October 2020

Published December 2020

*The authors declared no conflict of interest for this title or article

\begin{abstract}
While the global response to climate change has been scant and uncoordinated, especially with regard to providing adequate water resources for the most improvised, water scarcity has become an increasingly neglected phenomenon in rural areas. The long-term imbalance resulting from the water demand exceeding the available water resources has been identified in the literature, with the majority of rural dwellers negatively affected by water scarcity. Using a scoping review technique to explore the nexus between climate change and water-security realities in view of coping and planning mechanisms in the South African context, 246,443 articles published between 2010 and 2019 were collated and reviewed in a bid to ascertain the state of knowledge, study, and focus on the coping and planning strategies adopted by rural communities in the face of climate change-induced water insecurity in South Africa. The identified gaps in the literature indicate the omission of spatial planning principles in responding to water-scarcity issues. This review concludes that, although policy research that links the impacts of climate change in rural communities exists, stronger focus on the quality and quantity issues in the implementation of watersecurity matters is critical. Hence, the impact of climate change on climate-sensitive supplies available in these rural areas as well as the consequent coping and planning alternatives for rural communities require a more robust policy and spatial research. Thus, as rural communities deal with the impacts of climate change, implementation cycles of water-security measures need to be ensured along with further integration of spatial planning issues in rural areas. Hence, a deeper engagement with spatial planning issues is needed, in order to further mitigate and address the impacts of climate change on water security in rural areas.
\end{abstract}

Keywords: Climate change, coping strategies, rural communities, spatial planning, water security

\section{OMVANGSBEPALING TUSSEN KLIMAATSVERANDERING EN WATERVEILIGHEIDSWERKLIKHEID OP DIE PLATTELAND VAN SUID-AFRIKA}

Alhoewel die wêreldwye reaksie op klimaatsverandering maar skraps en ongekoördineerd is, veral met betrekking tot die verskaffing van voldoende waterbronne vir die mees geïmproviseerde, het waterskaarste 'n toenemend verwaarloosde verskynsel in landelike gebiede geword. Die langtermynwanbalans as gevolg van waterbehoefte wat die beskikbare waterbronne oorskry, is in die literatuur geïdentifiseer, terwyl die meeste landelike inwoners negatief geraak is deur waterskaarste. Met behulp van 'n bestekopname-hersieningstegniek om die verband tussen klimaatsverandering en waterveiligheidsrealiteite te ondersoek in die lig van die hanteringsen beplanningsmeganisme in die Suid-Afrikaanse konteks, is 246,443 artikels wat tussen 2010 en 2019 verskyn het, saamgevat en hersien in 'n poging om die stand van kennis, studie en fokus op die hanterings- en beplanningstrategieë wat deur landelike gemeenskappe aangeneem is, vas te stel in die lig van klimaatsverandering wat wateronsekerheid in Suid-Afrika veroorsaak. Die geïdentifiseerde leemtes in die literatuur verwys na die weglating van beginsels vir ruimtelike beplanning om te reageer op kwessies oor waterskaarste. Hierdie oorsig kom tot die gevolgtrekking dat, hoewel daar beleidsnavorsing bestaan wat die gevolge van klimaatsverandering in landelike gemeenskappe verbind, is 'n sterk fokus op die kwaliteit- en kwantiteitskwessies by die implementering van watersekerheidsaangeleenthede van kritieke belang. Die impak van klimaatsverandering op klimaatsensitiewe voorrade wat beskikbaar is in hierdie landelike gebiede, sowel as die gevolglike alternatiewe vir die hantering en beplanning van landelike gemeenskappe vereis dus kragtiger beleid en ruimtelike navorsing. Aangesien landelike gemeenskappe die gevolge van klimaatsverandering hanteer, moet die implementeringssiklusse van watersekuriteitsmaatreëls verseker word, tesame met verdere integrasie van ruimtelike beplanningskwessies in landelike gebiede. Daarom is ' $n$ dieper betrokkenheid by kwessies oor ruimtelike beplanning nodig om die gevolge van klimaatsverandering op die watersekuriteit in landelike gebiede verder te verminder en aan te spreek.

Sleutelwoorde: Hanteringsstrategieë, klimaatsverandering, landelike gemeenskappe, ruimtelike beplanning, waterveiligheid

Dr Patrick Hosea (corresponding author), Post-Doctoral Fellow (Global Migration and Community Development), School of Built Environment \& Development Studies, College of Humanities, University of KwaZulu-Natal, South Africa. Phone: 27312601449, email: <PatrickH@ukzn.ac.za>, ORCID: https://orcid.org/0000-0001-8022-9099.

Prof. Ernest Nene Khalema, Dean and Head of the School of Built Environment \& Development Studies, College of Humanities, University of KwaZulu-Natal, C872 Denis Shepstone Building (Howard College), Mazisi Kunene Road, Glenwood, Durban, 4041 , South Africa. Phone: +2731 260 1759, email: <khalema@ukzn.ac.za>, ORCID: https://orcid.org/0000-0002-6353-46897. 
HO LEKOLA KHOKAHANO LIPAKENG TSA PHETOHO EA MAEMO A LEHOLIMO LE MAEMO A TS'IRELETSO EA METSI MAHAENG A AFRIKA BOROA

Le ha mehato ea lefats'e mabapi le phetoho ea maemo a leholimo e le nyane ebile e sa hokahanngoa, haholoholo mabapi le ho fana ka metsi a lekaneng ho karolo ea sechaba e futsanehileng ka ho fetesisa, khaello ea metsi e se e le ntho e hlokomolohuoang haholo libakeng tsa mahaeng. Ho se lekalekane ha nako e telele ho bakoang ke tlhokeho ea metsi ho feta mehloli ea metsi e fumanehang, ho fumanoe lingoliloeng, mme boholo ba baahi ba mahaeng ba anngoe hampe ke khaello ea metsi. Ho sebelisa mokhoa oa ho lekola khokahano lipakeng tsa phetoho ea maemo a leholimo le maemo a polokeho ea metsi ka khokahanyo le mekhoa ea ho sebetsana le ho rala maemong a Afrika Boroa, lingoloa tse 246,443 tse phatlalalitsoeng lipakeng tsa 2010 le 2019 li ile tsa bokelloa le ho hlahlojoa ka sepheo sa ho netefatsa boemo ba tsebo, ho ithuta, le ho tsepamisa maikutlo mokhoeng oa ho sebetsana le merero e amoheloang ke sechaba sa mahaeng ha ba tobane le ts'ireletso ea metsi e bakoang ke phetoho ea maemo a leholimo Afrika Boroa. Likheo tse khethiloeng ka har'a lingoliloeng li supa ho siuoa hoa metheo ea moralo oa sebaka ho arabela litaba tsa khaello ea metsi. Tlhatlhobo ena e phethela ka hore, leha patlisiso ea maano e hokahanyang litlamorao tsa phetoho ea maemo a leholimo metseng ea mahaeng e le teng, ho tsepamisoa maikutlo ho matla ho boleng le bongata ba ts'ebetsong ts'ebetsong ea litaba tsa ts'ireletso ea metsi ho bohlokoa. Kahoo, tshutshumetso ea phetoho ea maemo a leholimo holima lisebelisoa tse amanang le maemo a leholimo, tse fumanehang libakeng tsena tsa mahaeng hammoho le mekhoa e meng e sebetsanang le maemo le meralo bakeng sa sechaba sa mahaeng e hloka leano le matla le lipatlisiso tse lekolang libaka ka kotloloho. Kahoo, ha sechaba sa mahaeng se sebetsana le litlamorao tsa phetoho ea maemo a leholimo, methati ea ts'ireletso ea metsi e hloka ho netefatsoa hammoho le kopanyo e tsoelang pele ea litaba tsa moralo oa libaka libakeng tsa mahaeng. Kahoo, ho hlokahala hore ho be le puisano e tebileng le litaba tsa moralo oa libaka, molemong oa ho fokotsa le ho sebetsana le litlamorao tsa phetoho ea maemo a leholimo ho ts'ireletso ea metsi libakeng tsa mahaeng.

\section{INTRODUCTION}

Water is essential for life, livelihood, and livelihood support. The right to water is enshrined in the Constitution of South Africa (Edokpayi, EnitanFolami, Adeeyo, Durowoju, Jegede \& Odiyo, 2020: 187; Eman \& Meško, 2020). However, ensuring the enforcement of such rights in the face of the impact of climate change requires systematic thinking in terms of water security (Edokpayi et al., 2020: 187; Millington \& Scheba, 2020: 5$)$. There is global scientific consensus on the significant hydrological alteration that climate change will evoke (Honkonen, 2017: 7; Babel, Shinde, Sharma \& Dang, 2020: 1). However, the direction, magnitude, and impact of climate change on the global, regional, and local communities is largely unclear (Liuzzo \& Freni, 2019: 2, 13; Haile, Tang, HosseiniMoghari, Liu, Gebremicae, Leng et al., 2020: 5). Cisneros (2015: 12-13), among others, asserted that the impact of climate change will predominantly be water related. Despite the continuous efforts by actors on the global, regional, national, and local levels on mitigation and adaptation to climate impacts especially on water, the situation of water (in)security seems to increase rather than diminish. The response in terms of coping mechanisms and strategies ${ }^{1}$ of individuals and societies alike to these uncertainties in Africa and other developing communities, especially in the global south, are, in most instances, blurred.

The case of South Africa's water security and the impending impact of climate change have become a policy, socio-economic and research concern. The need for spatial planning targeted at coordinating or "integration of the spatial dimension of sectoral policies through a territorially based

\footnotetext{
1 George et al. (2016) conceptualised a coping strategy as specific behavioural and/ or psychological actions undertaken by people as responses in an effort to reduce, minimize or endure a stressful event. Within this discourse, we imply the spatial planning principles and strategies in responding to water-scarcity issues.
}

strategy" (Cameron \& Katzschner, 2017: 200), and coping mechanism especially in rural communities in the face of these climate-change realities are enormous. This follows Rohr, Cilliers and Fourie's (2017: 13) postulation that work on spatial planning that focuses on sustainable water management is considerably limited. It becomes imperative to ascertain the state of knowledge, study, and focus on the coping and planning strategies adopted by rural communities in the face of climate change-induced water insecurity in South Africa.

It is pertinent to note that, while South Africa's approach to climate change has been to establish governance frameworks such as the National Planning Commission Medium Term Strategic Framework, 2009-2014; the National Development Plan, 2011; the Department of Environmental Affairs National Climate Change Response, 2012, and the Carbon Tax Policy, 2013, among others, studies show that these policies are yet to be translated into everyday practice among the South African populace, especially in the rural communities (Ziervogel, New, Archer van Garderen, Midgley, Taylor, Hamann et al., 2014: 614; Patrick, 2020:

$2)$. It has also been observed that water shortages have already been experienced in five of the 19 watermanagement areas in South Africa, with over 6,500 rural communities facing acute water shortages (VonBormann, 2014: 8-9; Patrick, 2019: 50). Action Aid (2016: 5) projects a $17 \%$ gap in water supply and demand by 2030 , with cities such as Johannesburg, Pretoria, Cape Town, and Durban experiencing the greatest challenge in water management.

Ziervogel et al. (2014: 610) argued that, in a bid to reconcile the water supply-and-demand gap in South Africa, it is imperative to increase the available water supply by about $2.5 \mathrm{~km}^{3}$ and decrease water withdrawal by $0.57 \mathrm{~km}^{3}$ by 2030 . Although this intervention may slow the imminent water stress, it is, however, argued that water demand will exceed supply annually through 
to 2035 (Mander, Jewitt, Dini, Glenday, Blignaut, Hughes et al., 2017: 263; Nieuwoudt, Grundling, Du Toit \& Tererai, 2018: 27; Mabhaudhi, Nhamo, Mpandeli, Nhemachena, Senzanje, Sobratee et al., 2019: 2). Similarly, Du Plessis (2017: 67) posited that, while the country is experiencing a multifaceted water crisis, it will experience a doubling of its total requirement for water in three decades, due to continuous demographic growth, economic development, and urbanisation. Eman and Meško (2020); Millington and Scheba (2020: 1-3); Haile et al. (2020: 18-19), and Zubaidi, OrtegaMartorell, Al-Bugharbee, Olier, Hashim, Gharghan et al. (2020: 2, 3), among others, also argue that water security is a function of population growth, resources depletion, and structural factors. The above situation portrays a looming sociopolitical and economic challenge, especially in terms of the water security of rural communities in South Africa.

This article reviews the impact of climate change and water security in South Africa, with a focus on the response mechanism for rural communities in view of the dynamic and historical configuration of the South African state. The essence is not to proffer solutions to water insecurity and the climate change nexus, but rather to provoke responses as well as set a background for contextualizing the nature and rationale for coping mechanisms in the face of the impact of climate change on water security in South Africa.

\section{METHODS AND REVIEW APPROACH}

The article adopts a scoping review technique to explore the nexus between climate change and water-security realities in view of the coping and planning mechanism adopted in the South African context. In this sense, a scoping review is regarded as a technique in mapping and summarizing evidence-based research targeted at identifying the priorities and gaps of a research phenomenon, in order to inform a policy review and future research (Munn, Peters, Stern, Tufanaru, McArthur \& Aromataris, 2018: 2-3; lenca, Ferretti, Hurst, Puhan, Lovis \& Vayena, 2018: 3). The approach involves the identification of the central research question for the study. In this case, the study seeks to answer the question: What is the state of knowledge, study, and focus on the coping and planning strategies adopted by rural communities in the face of climate change-induced water insecurity in South Africa? To do this, there was the need to identify and select relevant studies, data charting, and the collation of summaries and reports using a bibliometric analysis (lenca et al., 2018: 3-5).

The process led to the gathering and critical review of studies, grey literature, and online information between 2010 and 2019. The study used Google Scholar, ISI, ProQuest, and Scopus search engines to locate these studies, using keywords such as 'climate change', 'water security', 'planning', and 'coping strategies', in general. These keywords were then merged to include 'Africa' and 'South Africa', in particular. Table 1 shows that, from the 246,443 articles that were recorded for climate change, 66,106 articles dwelt on climate change and water, in general. The review was narrowed down to 3,161 articles that dealt with climate change and water security, and further to 472 articles that discussed climate change, water security, and planning. In addition, from the search, only 38 articles dwelt on all the keywords in relation to Africa. It is interesting to note that of the 105 articles on climate change, water, and planning in South Africa, only 10 studies discussed climate change and water security per se in relation to planning in South Africa (Ziervogel, Shale \& Du, 2010: 94-110; Mander et al., 2017: 261-271; Nieuwoudt et al., 2018: 26; Papadouris \& Thopil, 2018: 1767-1780; Mabhaudhi et al., 2019: 14; Rodina, 2019: 10-16). Only eight articles discussed adaptation in South Africa (Kahinda, Taigbenu \& Boroto, 2010: 742-750; Ziervogel et al., 2010: 97-105; Myers, Gaffikin, Golden, Ostfeld, Redford, Ricketts et al., 2013: 18753-18760; Mabhaudhi, Chimonyo \& Modi, 2017: 2-17; Mabhaudhi et al., 2019: 2-16; Rodina, 2019: 11-15). The review adopted convenience sampling to analyse and discuss $n=472$ articles that focused on climate change, water security, and planning. The data were triangulated with document reviews and organisational documents and analysed for meaning and relevance to the research question, using thematic content analysis. The guiding theme was the use of keywords such as 'climate change', 'water security', 'planning', and 'adaptation' as guiding themes. This provided a contextual background that explored the coping and planning mechanisms available for rural communities in South Africa in view of the climate change and water security nexus.

\section{KEY ISSUES}

To provide a context for the review, a brief conceptualization of climate change is imperative at this stage. Climate change refers to all forms of changes in climatic consistency, regardless of their statistical nature or physical cause, over a long period (Patrick, 2019: 17). It is viewed as what we experience when there is an upward or downward permanent shift

Table 1: Summary of articles search

\begin{tabular}{|l|c|}
\hline \multicolumn{1}{|c|}{ Keywords combination } & Number of articles \\
\hline Climate change & 246,443 \\
\hline Climate change + Water & 66,106 \\
\hline Climate change + Water security & 3,161 \\
\hline Climate change + Water security + Planning & 472 \\
\hline Climate change + Water security + Planning + Africa & 38 \\
\hline Climate change + Water + Planning + South Africa & 105 \\
\hline Climate change + Water security + Planning + South Africa & 10 \\
\hline Climate change + Water security + Planning + Adaptation + South Africa & 8 \\
\hline
\end{tabular}


of the average weather conditions in geographical space and time. The Intergovernmental Panel on Climate Change (IPCC, 2014: 120) defines climate change as
"... a change in the state of the climate which can be identified by the changes in the mean and/ or the variability of its properties, that persist for an extended period of time, typically decades or longer. It refers to any change in climate over time whether due to natural variability or a result of human activity."

From this definition, climate change is viewed as a long-term, gradual, but continuous change in the mean average weather conditions of the earth's surface, and as a significant alteration in climate patterns over a long period of time, which may be due to human and natural causes (Liuzzo \& Freni, 2019: 2). Climate change thus manifests itself through changes in climatic variables such as the increase in average global temperature, rise in sea level, changes in precipitation patterns, and extreme events (Patrick, 2019: 17; Zubaidi et al., 2020: 2).

\subsection{The impact of climate change on South Africa}

Millions of people have already experienced the impact of climate change on South Africa (Ziervogel et al., 2014: 606; Mander et al., 2017: 262). Kusangaya, Warburton, Van Garderen and Jewitt (2014: 47-48) argued that these impacts are expected to affect all spheres of life within the country and region as a whole. Zubaidi et al. (2020: 2) assert that climate changes in Southern Africa are already causing a shift in rainfall patterns, droughts, increase in health hazards, declining biodiversity, and wildlife extinction, as well as a general decline in ecosystem services. In discussing the climate change trends in South Africa, Jury's (2013: 2) study observed a declining rainfall trend in Eastern South Africa, a wet Northern South Africa, and a dry Southern South Africa pattern. Kusangaya et al. (2014: 47) argued that climate change in South Africa will affect energy use and agricultural productivity, flood control, wildlife management as well as industrial and domestic water supply. Action Aid (2016: 15) observed that 2015 was the driest year on record for South Africa. It argued that the country is already experiencing the worst drought since 1982, which has affected roughly 173 of the 1,628 water supply schemes serving 2.7 million households in South Africa. Using the Centre for Research on the Epidemiology of Disasters' (CRED) data, Pharoach et al (2016), cited in Patrick (2019: 31) argued that, within the past 20 years, South Africa has experienced roughly 65 natural and industrial disasters, with floods, storms, and droughts being the most common. The study asserted that the country experienced 23 floods, leading to 473 deaths and 483,965 people affected, as well as 19 storm events, leading to 154 deaths and 140,945 people affected. Although the study recorded only two drought events, it asserted that over 15.3 million people were affected. In terms of flood events, Gosling (2015: 1) observed an increase in the number of flood events in South Africa from 200 flood events between 1971 and 1980 to approximately 1,900 flood events between 2001 and 2010. This indicates that the impact of climate change-induced disasters will have an enormous impact on the country, as it will add yet another dimension to the existing challenges facing the country.

Nyam, Kotir, Jordaan, Ogundeji and Turton (2020: 62) argue that the vulnerability of South Africa is largely due to its low adaptive capacity, low technological uptake, and widespread poverty, especially in the rural areas. This is also combined with a high dependence on climate-sensitive livelihoods. Hence, the impact of climate change especially on water will have both a direct and indirect effect on the socio-economic and biophysical environments in South Africa. Mastrorillo, Licker, Bohra-Mishra, Fagiolo, Estes and Oppenheimer (2016: 156) observed that poverty and racial inequalities, which are partially the legacies of apartheid, thus make a specific subgroup within the population more vulnerable to the impact of climate change. Dlamini and Kaya (2016: 139) argue that the environmental insecurity facing South Africa as a whole is largely due to environmental mismanagement or inequality or both. Ziervogel et al. (2014: 606) advance that the impact of climate change will pose an acute challenge in South Africa in view of the level of poverty and inequality evident within the society. Ziervogel et al. (2014: 606-607) argue that the areas most sensitive to the impact of climate change in South Africa will be those characterized by subsistence food production and economic poverty, especially in the rural areas. This assertion motivates Kusangaya et al.'s (2014: 47), Mabhaudhi et al.'s (2019: 2,6), and Millington and Scheba's (2020: 6) arguments that mostly the poor will feel the hardship, due to the impact of climate change in South Africa.

Turpie and Visser (2013: 67) argue that the rural areas account for approximately $40 \%$ of South Africa's population. These areas are directly and indirectly dependent on natural resources (land and water) for their livelihood. It can, therefore, be expected that the impact of climate change on water and, by extension, agricultural output will have a direct effect on South Africa's rural communities in terms of reduced income and employment. This will have a knock-on effect for the rural community as a whole and, by extension, put a strain on the rural local government. The study argues that climate change affects the net revenue of the already vulnerable and has the potential to destabilize the whole region. Hence, climate change is expected to exacerbate rural poverty in South Africa. Hitayezu, Zegeye and Ortmann (2014: 555) adopt a systemic review method in assessing the extent of vulnerability to climate change in the Midlands region of KwaZulu-Natal. The study observes that vulnerability is compounded by high population density and over-dependence on rain-fed agriculture, among others. In line with this assertion, the DWA (2013: 121) contends that roughly 
8.5 million people in South Africa are directly or indirectly dependent on agriculture for their livelihood and employment. Hitayezu et al. (2014: 567-571) argue that the adaptive capacity of the populace is negatively affected by inadequate access to infrastructure, low literacy rate, high HIV prevalence rate, and low-income prospects. While Mastrorillo (2016: 161), citing World Bank (2014: 2), asserts that $58.3 \%$ of South Africa's population are below the national poverty line, Stats SA (2014: 34), however, asserts that KwaZulu-Natal accounts for over $26 \%$ of poverty in South Africa, with over $56.3 \%$ of the population in the province living in poverty. Poverty in this sense is contextualized in terms of the United Nations' definition of absolute poverty to imply a situation of deprivation of basic human needs, due not only to limited income, but also to the capacity for access (Hagenaars, 2017: 149). Hence, the impact of climate change on the rural poor will be adverse.

\subsection{The climate change and water security nexus}

It is pertinent to note that, while climate change and water are intricately interwoven, unprecedented social and environmental impacts due to climate change are mostly inevitable (Babel et al. 2020: 1-2). These effects pose an enormous challenge to the sustainability of water security, as Africa is projected to experience an even greater impact (Zadawa \& Omran, 2018: 129-130). According to the United States Geological Survey (nd), freshwater accounts for less than $3 \%$ of global water. Of this amount, $2.5 \%$ is frozen in glaciers, while the percentage amount readily available to meet the world's water demands is approximately $0.6 \%$. With climate change in the picture, the situation of water security becomes a global challenge capable of leading to water scarcity in different regions of the world. In view of this, Green, Vörösmarty, Harrison, Farrell, Sáenz and Fekete (2015) argue that freshwater provision for roughly $82 \%$ of the global population is exposed to varying degrees of threat. Honkonen (2017: 3 ) argues that the impact of the water crisis poses the largest global risk in view of its potential impact. Green et al. (2015) argue that roughly $80 \%$ of the world's population face a moderate to high level of threat relating to freshwater. Based on the above, water scarcity is conceptualized as the situation where the volume of water withdrawn from lakes, rivers, or groundwater becomes inadequate to meet human or ecosystem requirements, thus resulting in increased competition between users and demand.

Cook and Bakker (2012: 97-98) argued that there are three dimensions of water security in relation to different disciplines and viewpoints. These dimensions revolve around water-related hazards and vulnerability; human needs in terms of access, food security and human development-related concerns, and water sustainability. In terms of water-related hazards and vulnerability, water security involves the protection of vulnerable water systems, sustainable development of water resources, protection against water-related hazards, and safeguarding access to water. In line with the human needs dimension, on the other hand, water security is regarded as a condition in which water is available in sufficient quantity and quality as well as at an affordable price, in order to protect the safety, welfare, health, and productive capacity of households and communities in both the short and the long term. The third dimension of water security revolves around water sustainability. In modifying this conceptualization of water security, the United Nations' (UN-Water, 2013) analytical brief on water security added "sustainability" to the discourse on access to water. It also broadened the definition by adding sustainable livelihood and socioeconomic development, preservation of the ecosystem, as well as the issue of peace and political stability. Hence, UN-Water (2003: 1) defined water security as the

"capacity of a population to safeguard sustainable access to adequate quantity of acceptable quality of water for sustaining livelihoods, human being and socio-economic development, for ensuring protection against water borne pollution and water related disasters, and for preserving the ecosystems in a climate of peace and political stability."

UN-Water (2013: 1) and Xia, Duan, Luo, Xie, Liu and Mo (2017: 64) argued that the continuous changes in spatiotemporal patterns and precipitation variability affect the capacity for restoring natural water resources. Hence, a decrease in freshwater as greenhouse gases (GHG) emission increases, leading to climate change. The UN-Water (2013: 2) study projected a $40 \%$ decline in global freshwater supply by 2030 and a $55 \%$ increase in water demand by 2050 . Thus, one in every 10 people globally will experience lack of access to water. Cisneros (2015: 14-15) projected an increase in global water demand of $50 \%$ and $18 \%$ in developing and developed countries, respectively. The study also argued that over $60 \%$ of people who have access to water do not receive water supply in a proper and reliable way. Adding to this line of argument, Schewe, Heinke, Gerten, Haddeland, Arnell, Clark et al. (2014: 3245) asserted that
"a $2^{\circ} \mathrm{C}$ increase in global temperature above present level, which approximately will be $2.7^{\circ} \mathrm{C}$ more than the pre-industrial level, will lead to drastic water shortage for $15 \%$ of global population. This will also increase by approximately $40 \%$ the number of individuals experiencing absolute water shortage at less than $500 \mathrm{~m}^{3}$ per year."

Ziervogel et al.'s (2010: 95-97) study on Cape Town water supply and climate-change adaptation argued that developing countries' commitment and adaptation capacity of government in the management of water supply is, in most cases, lacking. Thus, climate change will exacerbate water stress in areas that are already pressurised by water scarcity or near water stress. In support of this claim, the UNFCCC (2011: 4, 5), Zadawa and Omran (2018: 130), and Patrick 
(2020: 2) projected that Africa will face increased water stress and conflict, as average temperatures across the continent continue to rise and rainfall declines. By 2020, 75 to 200 million people in Africa will face severe water shortages. In line with this position, over $35 \%$ of the population in Africa already have no access to safe drinking water at varying degrees (Martínez-Santos, 2017: 522; Edokpayi et al., 2020: 190). Action Aid (2016: 10) asserted that over $50 \%$ of the 663 million people who continue to use unsafe drinking water globally reside in Africa. Similarly, while over 600 million people have had no access to water since 2010 , roughly 240 million (approximately $40 \%$ of the total) are in Africa (Cisneros, 2015: 13). In light of this, the effect of water security will be determined by the geographical location and characteristics of an area; the condition of water availability and use; the resilience of the ecosystem to climate variability; demographic changes; prevailing management and allocation system, as well as the existing institution and governance structure.

\subsection{Climate change and water resources in South Africa}

Papadouris and Thopil (2018: 1768) and Nyam et al. (2020: 62) argue that South Africa's vulnerability to the impact of climate change on water is largely due to its general aridity. The changes in water supply vis-à-vis the impact of climate change will thus have adverse implications for several sectors of the economy. Hence, Hannah, Roehrdanz, Ikegami, Shepard, Shaw, Tabor et al. (2013: 6907) argue that the potential damage of climate change on freshwater supply will be severe and felt mostly in areas already experiencing water scarcity. It is, therefore, pertinent to note that the South African water sector faces the challenge of limited water resources, due to the water-stressed nature of the country and the need to ensure an equitable distribution of this scarce water resource. In view of this, Hedden and Cilliers (2014: 2), Rodina (2019: 11-12) and
Nyam et al. (2020: 62) argue that the unpredictability of water supply, coupled with high demand and poor use of existing resources, makes the country water constrained. Zhu and Ringler's (2010) study on the impact of climate change on water resources in the Limpopo River Basin argues that climate change will impact severely on the hydrological resources in South Africa and add pressure on future adaptation. Hence, the depletion in water resources will lead to an increase in the cost of water and water rationing, among others. Ziervogel et al. (2010: 105) argue that the country is facing the dilemma of creating an equilibrium between social, economic, and environmental priorities, as it addresses the impact of climate change especially on water supply and demand. Lucas (2015: 20) argues that, with roughly $98 \%$ of South Africa's water already being used, over half of the country's water supply comes from $14 \%$ of the country's rivers located mainly along the Eastern coastal region.

As at 2015, water storage in South Africa was at $64.3 \%$ of the normal supply compared to $74.6 \%$ storage level in 2014. It is projected that the country is likely to exceed its economically useable land water resources by 2050 . This situation was observed by the DWA (2013: 37) report which argues that South Africa is at the brim of full utilisation of its available surface water. Lucas (2015: 20) projects a $1.7 \%$ shortage in water supply by 2025 , with a higher decline in water security in relatively dry catchment areas. Von-Bormann (2014: 24) observes a continuous decline in the quality of available freshwater, with approximately $40 \%$ of South Africa's freshwater system in critical condition and $80 \%$ threatened. The study projects a $17 \%$ gap in water supply and demand by 2030, with Johannesburg, Pretoria, Cape Town and Durban experiencing the greatest challenge for water management. DWA (2013: 20) asserts that domestic water consumption over the past decade in South Africa increased from $22 \%$ to approximately $27 \%$. Hence, the demand for water over the next decade is projected to increase by $1.2 \%$. In view of this contention, Hedden and Cilliers (2014: 2) assert that South Africa's average per person/per day water consumption level of 235 litres is above the global average of 173 litres per person/per day. Hence, using the international future global forecasting system model that produces atmospheric simulations in providing numerical predictions based on a wide range of atmospheric and land-soil variables (Powers Klemp, Skamarock, Davis, Dudhia, Gill et al., 2017: 1720), the study asserts that the gap between water demand and supply is steadily increasing. This was simulated using associated forecast to 2030 and 2035 (the time frames for the SA National Development Plan and the National Water Strategy). It, therefore, argues that measures undertaken by the DWA in bridging the demand and supply gap needs to be more aggressive to stand a chance of succeeding. In view of this assertion, Zhuwakinyu (2012: 2) posits that this gap in water supply and demand will equate a water shortfall of approximately 2.7 billion cubic metres. More recent studies by, among others, Rodina (2019: 11-15) of Cape Town, Zubaidi et al. (2020: 3-13) of Gauteng province, and Nyam et al. (2020: 62), all support thecontention that the water supply and demand gap is no longer a future challenge, but a present issue in South Africa.

In view of this, Oxfam (2010:2) argue that water scarcity in South Africa is aggravated by maladministration of irrigation schemes as well as the improper maintenance of the irrigation canals and extension services. Von-Bormann and Gulati (2014: 21-25) argue that the declining quality and quantity of water resources in the country pose a serious challenge for South Africa. Oxfam (2010: 21) argued that water-resource management in South Africa is a time bomb waiting to explode. This is motivated by the continuous decline in access to water by millions of South Africans, due to the decrease in water availability 
and poor resource management or privatization of water management.

The World Bank (2014: 4) asserts that, due to the challenges of water in the country, over 3 million people in South Africa have no access to water. Government's basic water services are mainly in the urban areas, while the rural areas are mostly dependant on climatesensitive natural resources such as groundwater, springs and rivers, which are vulnerable to droughts and flooding. Ntsaluba (2014: 1) asserts that roughly $14 \%$ of the country's population have no access to clean water. In their study on governance's adaptation to climate change in the water sector, Huntjens Lebel, Pahl-Wostl, Camkin, Schulze and Kranz (2012: 75-80) argue that the institutions in the Southern African region lack the ability to manage the challenges related to water security such as, among others, drought, floods, rise in sea level, watersupply shortages, increase in water pollution, and water-related diseases. Ziervogel et al. (2010: 95-97) explore the institutional context of actors' response to water-supply management in Cape Town and the extent to which climate change is considered. The study found that the capacity of government to respond to water supply is often inadequate and that there is a significant gap between policy and practice in developing countries.

The study further argues that South Africa's water-management policy and planning are characterised by complex sociocultural, economic, and political challenges that need to be addressed. Exemplifying this assertion, the study observes that the informal settlements in Cape Town, with poor access to water, live alongside wealthy neighbourhoods with cheap and reliable access to water supply. In addition, the adaptation strategies in cities such as Durban are often disrupted, due to resource shortages and the need to channel resources to other priority areas.

Knopges (2016: 45) asserts that the decrease in water availability in
South Africa, either due to natural causes or as a result of infrastructural mismanagement, poses grave consequences for industries, agriculture, and the economy as a whole. In this vein, Gain and Gupponi (2012: 126) argue that the impact of climate change on water will create not only a deficiency in water availability and demand, but also higher order effects for other sectors. Hence, the impact of climate change on water security in South Africa has a direct effect on the agricultural output of rural communities, thereby increasing the poverty and vulnerability of the rural poor. Hughes and Mather (2014: 31 ) support this claim and argue that several poor people are heavily dependent on ecosystem services that are specifically vulnerable to the impact of climate change. Von-Bormann (2014: 15-17) argues that approximately 8.5 million people in South Africa rely directly or indirectly on agriculture for employment and income. Action Aid (2016: 22) asserts that a decrease in water quality and usability could result in the loss of over 200,000 jobs across South Africa and a drop in disposable income by $5.7 \%$ per person. Hence, although the South African economy is dominated by the tertiary sector, agriculture is still relevant for its development and stability. This supports Nel, Maitre, Roux, Colvin, Smith, Smith-Adao et al.'s (2017: 252-254) argument that development is constrained in South Africa as a result of the difficulty in ensuring the availability of water. This is an effect of the knock-on effects of water shortage on other water-reliant sectors.

Ntsaluba (2014: 1) and SAHRC (2014: 15) observe that the hardest hit water-stressed provinces are also the country's most important foodproduction areas. Kings (2015: 1 ) asserts that over 400,000 head of cattle have died and that roughly 150,000 people receive disaster aid in the form of water and food. The SAHRC report (2014: 19) argues that 99 municipalities (roughly $38 \%$ of the total), which are predominantly in rural communities in KwaZulu-Natal,
North West, and Eastern Cape, are experiencing a water crisis. An average of $22.2 \%$ (Eastern Cape), $14.1 \%$ (KwaZulu-Natal), 14\% (Limpopo), 12.6\% (Mpumalanga) of the population have no access to piped water. As of 2011, less than $80 \%$ of the population in KwaZuluNatal had access to water. Ntsaluba (2014: 1) argues that systemic failure in governance and implementation, especially in terms of project implementation, is a contributory factor to this plight. This situation has the potential to degenerate into a crisis (SAHRC, 2014). Addressing the water issue is, therefore, central to the adaptation to climate change.

\subsection{Climate change water resources and coping/ planning strategies}

In the discourse on the impact of climate change on human security, coping strategies are largely conditioned by the degree of vulnerability of individuals and/or groups to climate change-induced impact on human and environmental resources. This corresponds with the idea of response and survival from a real or perceived form of threats to survival. This study conceptualizes coping strategies as the short-term immediate cognitive and behavioural responses by individuals, households and/or communities to declining natural resources. Dari, Aboagye and Koomson (2013: 1) conceptualized coping strategies as an erosive or non-erosive response of individuals and/or groups to a perceived or actual stressful event. Hence, coping strategies are curative and reformative actions by individuals and/or groups whose survival is compromised or threatened. For Vincent, Cull, Chanika, Hamazakaza, Joubert and Macome (2013: 194), coping connotes short-term strategies conceived by individuals and/or groups to maintain survival.

The higher the degree of vulnerability, the lower the capacity to cope and the higher the tendency to adopt a mechanism for coping. Dari et al. (2013: 5-11) assert that vulnerability and capacity to cope are linked 
to structural, infrastructural and superstructural elements of the community. While the structural factors imply the socio-economic conditions as well as the extent and availability of service delivery in the community, the infrastructural element refers to the demographic, biological, and environmental characteristics of the community. The superstructure, on the other hand, speaks to the literacy, culture, values, and belief system of the community. In view of this, coping strategies are relative and conditioned by the combination of structural, infrastructural and superstructural elements of society, in addition to previous historical experiences. Hence, coping strategies are culturally specific. The choice of one coping strategy over another depends on the magnitude of the event as well as the characteristics of the individuals and/or households. This invariably suggests that the peculiarities of society in terms of, among others, education, wealth, and ethnic configuration form potentially relevant cleavage lines for the coping mechanism adopted. In line with this, Zheng and Byg (2014: 226) assert that vulnerability and coping strategies are largely characterised by varied socio-economic features of individuals and/or households. Hence, hydro-climatic variability and socio-economic alterations interact and reinforce society's coping strategy. These coping mechanisms could be adaptive, behavioural, defence, self-harm and/or aggressive in nature. They include, among many others, migration, sales of household assets, income diversification, collection of loans, violence, theft, child labour, remodelling of daily routine and practices, rationing and resources management, cooperation, and so on.

Mavhura, Manyena, Collins and Manatsa (2013: 38-45) explore variation in household coping ability and survival strategies adopted in terms of flooding situations in Muzarabani, Zimbabwe. The study argues that the degree of climate change-induced water insecurity on households is a function of not only the magnitude of the flood and/ or drought, but also the function of variables such as income, education, and occupation, among others. Using the theory of planned behaviour, the various coping mechanisms will be determined by the relativity of the households' structural, infrastructural and superstructural elements. From these assertions, Maystadt, Calderone and You (2014: 651-652) argue that the depletion in natural resources, particularly water resources, is the main driver for competition and conflict in North and South Sudan. Mukuhlani and Nyamupingidza's (2014: 145-157) study of coping strategies during water-scarcity situations in Bulawayo itemised positive and negative coping strategies adopted by government, communities, and households. These include 'water shedding' to stabilize the shrinking dam-water levels, water trucking, walking long distances to fetch water, buying water from other communities and water vendors, buying water containers to store water, as well as conflict, vandalism and abuse, among others. Their study asserted that conflict as a negative coping strategy occurs because of the inconsistency of water supply, especially during the peak of water shortage and rationing. Patrick (2020: 8) also argued that conflict as a coping mechanism occurs in situations where the opportunity cost for aggression outweighs the adoption of other response mechanisms. In his study of rural South Africa, Patrick (2020) posits that residents are more likely to be involved in violence as a means of communicating their grievances when resources are limited or nonexistent. In the same vein, AdenijiOloukoi, Urmilla and Vadi (2013: 29-35) explored coping strategies among households with regard to climate-induced water shortages in Nigeria. They observed that, while behavioural coping options were adopted in traditional households, technical coping options were embraced in urban neighbourhoods. However, most of the households adopted multiple coping mechanisms for water shortages. The study findings posited that the socioeconomic characteristics of households exerted an influence on the coping strategy options adapted.

Similarly, while discussing climate change and water stress peculiarities in South Africa in view of the coping mechanism adopted, Gandure, Walker and Botha's (2013: 39-50) study in Gladstone, Free State province, argued that inherent historical land access imbalances as well as the policies introduced by the government on free access to water and social grants have over time discouraged the need for adaptation, thus creating household dependency. Hence, the study argued that socio-economic peculiarities as well as political and historical factors underpin household coping strategies. Supporting this claim, Saul and Bond (2014: 64) argued that the country's access to and use of water is shaped by conditions rooted in the history of colonialism, segregation and apartheid as well as the political struggles it bred. Wilk, Andersson and Warburton (2013: 85-86) concluded that response to climatechange stress among households is a function of the households' construction of their reality as well as their ability to act and adapt in terms of their socio-economic characteristics. These assertions showed in many respects that the peculiarities of a sociopolitical and cultural setting influence, to a large extent, the coping strategies adopted by individuals and societies in response to the impact of climate change on water security.

Hellberg (2017: 74,76) posits that the country's access to and use of water are still shaped by conditions rooted in its historical legacies. The underlining peculiarities of South Africa vis-à-vis its historicity thus influence the nature of the response to water insecurity among households and communities. These coping mechanisms adopted across quarters in rural communities are diverse. In view of this, Adewumi, llemobade and Van Zyl (2010: 222, 224) posited that the trend for water reuse for 'non-drinking' necessities is 
becoming an increasing phenomenon across all quarters in South Africa, due to the impact of climate change on the country's already stressed water resources. The use of containers for irrigation purposes instead of pipes in a bid to avoid water wastage as well as the use of water-storage facilities in coping with the below average precipitation level for South Africa are identified as a strategy for water conservation in rural South Africa (UN-Water, 2013: 7; Knopges, 2016: 48). In rare instances where there is rainfall, the use of rainwater harvesting is also indicated as another viable option available for most of the households in rural communities in securing water for household use. Kahinda et al. (2010: 743-744) and Biazin, Sterk, Temesgen, Abdulkedir and Stroosnijder (2012: 139-142) corroborate this strategy as a means for household water security. They argue that rainwater harvesting serves as a pivotal channel for securing water for rural households in South Africa. While Biazin et al. (2012: 139) argued that the tactic cut across sub-Saharan Africa, Kahinda et al. (2010: 743) argued that it is an important source of water for rural communities in South Africa.

In other instances where residents are left with hardly any or no option, the buying and selling of water is considered another coping mechanism. In this scenario, residents are left with hardly any or no alternative but to buy water from water vendors, who, in most cases, sell water at ridiculous prices, due to the scarcity of water caused by the impact of climate change (Magubane, 2015: 1). The rise in protest action is also observed as a reoccurring response to water insecurity in South Africa. Studies by Chigwata, O'Donovan and Powell (2017: 1), Chambers (2018: 1), and Patrick (2020: 10-11) corroborate the assertion of increased protest actions as a communication mechanism used by the citizens to express their displeasure to the authority. This increases conflict situations in the face of dissatisfaction with resource-management processes in society. This is supported by Gleick's (2014: 338) studies which argue that the ability of governance institutions to manage waterrelated grievances determines the tendency for conflict in society.

In reviewing government's response to the impact of climate change on water, Saul and Bond (2014: 162) as well as Hellberg (2017: 75), among others, observed the lopsided responsibility of the state in addressing issues of access to water and service delivery in South Africa, especially in rural areas. Ziervogel et al. (2014: 612) observed a major lacuna between policy and practice in South Africa. This is largely due to systemic failure in governance and implementation capacity as a result of the weak institutional capability on the part of the government. The vulnerability of households to water extremes leading to water scarcity is, therefore, rooted in the institutional incapacity of the state to provide such resources. This situation for South Africa is embedded in poor management and planning for sustainable development. In several instances where state institutions did intervene or carry out their assigned responsibility, many believe that it is always reactionary (Patrick, 2020: 14). Patrick (2020: 12) further argued that the primacy of providing a minimum daily water requirement, especially for rural communities, is often neglected until a crisis erupts. Similarly, Theisen, Gleditsch and Buhaug (2011: 614-615) as well as Patrick (2019: 30, 67) argued that conflict over water, reflected as a negative response to water scarcity situations, is a result of negligence and abuse felt by a group of people over time.

\section{CONCLUDING REMARKS}

The aim of this article was to review the impact of climate change and water security in South Africa, with a focus on the response mechanisms for rural communities in view of the dynamic and historical configuration of the South African state. The rationale was to provoke responses as well as set a background for the discourse of coping mechanisms in the face of climate change and water security in South Africa. The studies reviewed summarily showed that climate-change realities and its impact in South Africa cannot be over-emphasised. The vulnerability of South Africa to climate changeinduced water insecurity is informed by its general aridity, increasing population, and economic growth as well as its infrastructural and management inadequacies. South Africa, therefore, faces a dilemma of creating an equilibrium between social, economic, and environmental priorities in addressing climate change-induced water security challenges. The vulnerability of rural communities in South Africa to these climate-change realities, especially water, is intensified by its weak coping capacity in terms of poverty, lack of infrastructure as well as overdependence on climate-sensitive resources. This has a negative effect on the livelihood of residents, especially in rural communities in South Africa. This vulnerability is also intensified by inadequacies in government's response to water insecurities, especially in rural areas, as well as the non-availability of basic water services mostly in these areas. The situation is further complicated by government postresilience strategies rather than pre-emptive pre-resilience strategies, making government's response reactionary rather than proactive. Hence, there is a need for more proactive measures by individuals, communities, and the government in managing climate change-induced water vulnerabilities in these areas.

This review concludes that, although policy research that links the impacts of climate change to water security in rural communities exists, a stronger focus on issues of quality and quantity in the implementation of water-security matters is critical. The review noted the dearth of studies focusing on adaptations, coping, and planning alternatives available for rural communities in South Africa to the impact of climate changeinduced water insecurity. There are no spatial planning principles 
to respond to water scarcity issues in South Africa, in general, and in rural communities, in particular. The historical peculiarities of South Africa, in terms of its socioeconomic and spatial configuration, place the rural communities in the rainbow nation in a somewhat disadvantageous position in terms of the supply of water. The impact of climate change on climatesensitive supplies available in these rural areas as well as the consequent coping and planning alternatives for rural communities require more robust policy and spatial research. Thus, as rural communities deal with the impacts of climate change, implementation cycles of water-security measures need to be ensured along with further integration of spatial planning issues in rural areas. There is also a need for a deeper engagement with spatial planning research and issues, in order to further mitigate and address the impacts of climate change on water security in rural areas, especially within the context of South Africa.

\section{REFERENCES}

ACTION AID SOUTH AFRICA. 2016. Running on empty: What business, government and citizens must do to confront South Africa's water crisis. Water Interrupted Campaign. South Africa.

ADENIJI-OLOUKOI, G., URMILLA, B. \& VADI, M. 2013. Households' coping strategies for climate variability related water shortages in Oke-Ogun region, Nigeria. Environmental Development, 5(1), pp. 23-38. https:// doi.org/10.1016/j.envdev.2012.11.005

ADEWUMI, J.R., ILEMOBADE, A.A. \& VAN ZYL, J.E. 2010.

Treated wastewater reuse in South Africa: Overview, potential and challenges. Resources, Conservation and Recycling, 55(2), pp. 221-231. https://doi.org/10.1016/j. resconrec.2010.09.012
BABEL, M.S., SHINDE, V.R., SHARMA, D. \& DANG, N.M. 2020. Measuring water security: A vital step for climate change adaptation. Environmental Research, vol.185, article no. 109400 , pp. 1-12. https://doi.org/10.1016/j. envres.2020.109400

BIAZIN, B., STERK, G., TEMESGEN, M., ABDULKEDIR, A. \& STROOSNIJDER, L. 2012. Rainwater harvesting and management in rainfed agricultural systems in sub-Saharan Africa - A review. Physics and Chemistry of the Earth, Parts $A / B / C$, vol. 47-48, pp.139-151. https://doi. org/10.1016/j.pce.2011.08.015

CAMERON, R. \& KATZSCHNER, T. 2017. Every last drop: The role of spatial planning in enhancing integrated urban water management in the City of Cape Town. South African Geographical Journal, 99(2), pp.196-216.

CHAMBERS, D. 2018. Fight in water queue forces Cape Town to crack down. Sunday Times newspaper. [Online]. Available at: <https://www. timeslive.co.za/news/south-africa/201801-31-fight-in-water-queue-forcescape-town-to-crack-down/> [Accessed: 20 April 2020].

CHIGWATA, T., O'DONOVAN, M. \& POWELL, D. 2017. Civic protests and local government in South Africa. Working Paper Series No. 2. The Civic Protests Barometer 20072016, Technical Note, 2017, Cape Town: ACSL, Dullah Omar Institute. [Online]. Available at: <http://www. dullahomarinstitute.org.za> [Accessed: 20 April 2020]

CISNEROS, J. 2015. Responding to the challenges of water security: The eight phases of the international hydrological program 2014-2021. In: Cudennec, C., Demuth, S., Mishra, A. \& Young, G. (Eds). Proceedings of the International Association of Hydrological Sciences (PIAHS), 16-17 June 2014, Paris, France, Hydrological Sciences and Water Security: Past, Present and Future, vol 366, pp.10-19. https://doi.org/10.5194/ piahs-366-10-2015, 2015. https://doi. org/10.5194/piahs-366-10-2015

COOK, C. \& BAKKER, K. 2012. Water security: Debating an emerging paradigm. Global Environmental Change, 22(1), pp. 94-102. https://doi. org/10.1016/j.gloenvcha.2011.10.011
DARI, T. ABOAGYE, A. \& KOOMSON, J. 2013. Coping with floods in the savannah region of Ghana. Arts and Social Sciences Journal, 61, pp. 1-12. https://doi. org/10.4172/2151-6200.1000061

DLAMINI, N. \& KAYA, H. 2016.

Environmental security, indigenous knowledge systems and implication for food security in South Africa. Journal of Human Ecology, 53(2), pp.135-140. https://doi.org/10.1080/09709274.2016 .11906965

DU PLESSIS, A. 2017. South Africa water availability and use. In: Du Plessis, A. (Ed.). Fresh water challenges of SA and its upper Vaal River. New York: Springer International, pp. 65-76. https://doi. org/10.1007/978-3-319-49502-6_4

DWA (DEPARTMENT OF WATER AFFAIRS). 2013. Annual national state of water report for the hydrological year 2012/2013. Department of Water Affairs.

EDOKPAYI, J.N, ENITAN-FOLAMI, A.M., ADEEYO, A.O., DUROWOJU, O.S., JEGEDE, A.O. \& ODIYO, J.O. 2020. Recent trends and national policies for water provision and wastewater treatment in South Africa. In: Singh, P., Milshina, Y., Tian, K., Gusain, D. \& Bassin, J.P. (Eds). Water conservation and wastewater treatment in BRICS nations.

Amsterdam, The Netherlands: Elsevier, pp. 187-211. https://doi.org/10.1016/ B978-0-12-818339-7.00009-6

EMAN, K. \& MEŠKO, G. 2020. Access to safe and affordable drinking water as a fundamental human right: The case of the Republic of Slovenia. In: Blaustein, J., Fitz-Gibbon, K., Pino, N.W. \& White, R. (Eds). The Emerald handbook of crime, justice and sustainable development. West Yorkshire: Emerald Publishing Limited, pp. 465-484. https:// doi.org/10.1108/978-1-78769-355520201025

GAIN, A. \& GUPPONI, C. 2015. A dynamic assessment of water scarcity risk in the lower Brahmaputra river basin: An integrated approach. Ecological Indicators, 48, pp. 120-131. https://doi.org/10.1016/j. ecolind.2014.07.034 
GANDURE, S., WALKER, S. \& BOTHA, J. 2013. Farmers' perception of adaptation to climate change and water stress in a South African rural community. Environmental Development, 5(1), pp. 39-53. https:// doi.org/10.1016/j.envdev.2012.11.004

GLEICK, P. 2014. Water, drought, climate change and conflict in Syria. American Metrological Society, 6(3), pp. 331-340. https://doi.org/10.1175/ WCAS-D-13-00059.1

\section{GOSLING, M. 2015. SA's}

water security in peril. Sunday Independent newspaper. [Online]. Available at: <http://www.iol.co.za/ sundayindependent/sas-water-securityin-peril-1901410.> [Accessed: 20 April 2020].

GREEN, P., VÖRÖSMARTY, C., HARRISON, I., FARRELL, T., SÁENZ, L. \& FEKETE, B. 2015. Freshwater ecosystem services supporting humans: Pivoting from water crisis to water solutions. Global Environmental Change, 34, pp. 108-118. https://doi. org/10.1016/j.gloenvcha.2015.06.007

HAGENAARS, A.J. 2017. The definition and measurement of poverty. In: Osberg, L. (Ed.). Economic inequality and poverty: International perspectives. London, UK: Routledge, pp. 148-170.

HAILE, G.G., TANG, Q., HOSSEINIMOGHARI, S.M., LIU, X., GEBREMICAEL, T.G., LENG, G. et al. 2020. Projected impacts of climate change on drought patterns over East Africa. Earth's Future, 8(7), article no, e2020EF001502, pp. 1-23. https://doi. org/10.1029/2020EF001502

HANNAH, L., ROEHRDANZ, P., IKEGAMI, M., SHEPARD, A.V., SHAW, M., TABOR, A. et al. 2013. Climate change, wine, and conservation. Proceedings of the National Academy of Sciences, 110(17), pp. 6907-6912. https://doi.org/10.1073/ pnas. 1210127110

HEDDEN, S. \& CILLIERS, J. 2014. Parched prospects - The emerging water crisis in South Africa. Institute for Security Studies Papers, 2014(11), p. 16. https://doi.org/10.2139/ ssrn.2690124

HELLBERG, S. 2017. Water for survival, water for pleasure $-A$ biopolitical perspective on the social sustainability of the basic water agenda. Water Alternatives, 10(1), p. 65.
HITAYEZU, P., ZEGEYE, E. \& ORTMANN, G. 2014. Some aspects of agricultural vulnerability to climate change in KwaZulu-Natal Midlands, South Africa: A systematic review. Journal of Human Ecology, 48(3), pp. 347-356. https://doi.org/10.1080/09709 274.2014.11906804

HONKONEN, T. 2017. Water security and climate change: The need for adaptive governance. Potchefstroom Electronic Law Journal/ Potchefstroomse Elektroniese Regsblad, 20(1), 1-26. DOI: 10.17159/1727-3781/2016/v19i0a1651

HUGHES, C. \& MATHER, A., 2014. Durban climate change strategy water theme report: Draft for Public Comment. [Online]. Available at: <http:// www.durban.gov.za/City_Services/ energyoffice/Documents/DCCS\%20 Water\%20Theme\%20Report.pdf>. [Accessed: 28 April 2020].

HUNTJENS, P., LEBEL, L., PAHLWOSTL, C., CAMKIN, J., SCHULZE, R. \& KRANZ, N. 2012. Institutional design prepositions for the governance of adaptation to climate change in the water sector. Global Environmental Change, 22(1), pp. 67-81. https://doi. org/10.1016/j.gloenvcha.2011.09.015

IENCA, M., FERRETTI, A., HURST, S. PUHAN, M., LOVIS, C. \& VAYENA, E. 2018. Considerations for ethics review of big data health research: A scoping review. PloS one, 13(10), article no. p.e0204937, pp.1-15. https://doi. org/10.1371/journal.pone.0204937

IPCC (INTERGOVERNMENTAL PANEL ON CLIMATE CHANGE). 2014. Impacts, Adaptation, and Vulnerability. Part B: Regional Aspects. Contribution of Working Group II to the Fifth Assessment Report of the Intergovernmental Panel on Climate Change. V. R. Barros, C. B. Field, D. J. Dokken, et al. (editors). Cambridge, United Kingdom and New York, NY, USA

JURY, M.R. 2013. Climate trends in southern Africa. South African Journal of Science, 109(1-2), pp. 1-11. https:// doi.org/10.1590/sajs.2013/980

KAHINDA, J.M., TAIGBENU, A.E. \& BOROTO, R.J. 2010. Domestic rainwater harvesting as an adaptation measure to climate change in South Africa. Physics and Chemistry of the Earth. Parts A/B/C, 35(13-14), pp. 742-751. https://doi.org/10.1016/j. pce.2010.07.004
KINGS, S. 2015. Too late to avert water disaster. Environment - Mail and Guardian. [Online]. Available at: <https://www.mg.co.za> [Accessed: 20 April 2020].

KNOPGES, B. 2016. Holding water. Dams and water storage. Institute of Municipal Engineering of Southern Africa, 41(1), pp. 46-50.

KUSANGAYA, S., WARBURTON, M., VAN GARDEREN, E. \& JEWITT, G. 2014. Impacts of climate change on water resources in southern Africa: A review. Physics and Chemistry of the Earth. Parts $A / B / C, 67$, pp. 47-54. https://doi.org/10.1016/j. pce.2013.09.014

LIUZZO, L. \& FRENI, G. 2019. Quantifying the uncertainty related to climate change in the assessment of urban flooding - A case study. Water, 11(10), article no. 2072, pp. 1-15. doi:10.3390/w11102072

LUCAS, M. 2015. Waterwise: How climate will affect our water supply. Quest: Science for South Africa, 11(4), pp. 20-23.

MABHAUDHI, T., CHIMONYO, V.G. \& MODI, A.T. 2017. Status of underutilised crops in South Africa: Opportunities for developing research capacity. Sustainability, vol. 9, article no.1569, pp. 1-22. https://doi. org/10.3390/su9091569

MABHAUDHI, T., NHAMO, L., MPANDELI, S., NHEMACHENA, C., SENZANJE, A., SOBRATEE, N. et al. 2019. The water-energy-food nexus as a tool to transform rural livelihoods and well-being in Southern Africa. International Journal of Environmental Research and Public Health, vol. 16, article no. 2970, pp. 1-20. doi:10.3390/ ijerph16162970

MAGUBANE, T. 2015. KwaZulu-Natal drought sparks violence. Crime and courts. [Online]. Available at: <http:// www.iol.co.za/news/crime-court/kzndrought-sparks.violence-1940963> [Accessed: 20 April 2020].

MANDER, M., JEWITT, G., DINI, J., GLENDAY, J., BLIGNAUT, J., HUGHES, C. et al. 2017. Modelling potential hydrological returns from investing in ecological infrastructure: Case studies from the BaviaanskloofTsitsikamma and uMngeni catchments, South Africa. Ecosystem Services, 27(Part B), pp. 261-271. https://doi. org/10.1016/j.ecoser.2017.03.003 
MARTÍNEZ-SANTOS, P. 2017. Does $91 \%$ of the world's population really have "sustainable access to safe drinking water"? International Journal of Water Resources Development, 33(4), pp. 514-533. https://doi.org/10.1080/07 900627.2017.1298517

MASTRORILLO, M., LICKER, R., BOHRA-MISHRA, P., FAGIOLO, G., ESTES, L.D. \& OPPENHEIMER, M. 2016. The influence of climate variability on internal migration flows in South Africa. Global Environmental Change, 39, pp. 155-169. https://doi. org/10.1016/j.gloenvcha.2016.04.014

MAVHURA, E., MANYENA, S.B., COLLINS, A.E. \& MANATSA, D. 2013. Indigenous knowledge, coping strategies and resilience to floods in Muzarabani, Zimbabwe. International Journal of Disaster Risk Reduction, 5, pp. 38-48. https://doi.org/10.1016/j. ijdrr.2013.07.001

\section{MAYSTADT, J., CALDERONE, M.} \& YOU, L. 2014. Local warming and violent conflict in North and South Sudan. Journal of Economic Geography, 15(3), pp. 649-671. https:// doi.org/10.1093/jeg/lbu033

MILLINGTON, N. \& SCHEBA, S. 2020. Day Zero and the infrastructures of climate change: Water governance, inequality, and infrastructural politics in Cape Town's water crisis. International Journal of Urban and Regional Research. Forthcoming. https://doi. org/10.1111/1468-2427.12899

MUKUHLANI, T. \& NYAMUPINGIDZA, M. 2014. Water scarcity in communities, coping strategies and mitigation measures: The case of Bulawayo. Journal of Sustainable Development, 7(1), pp. 144-160. https://doi.org/10.5539/jsd.v7n1p144

MUNN, Z., PETERS, M.D., STERN, C., TUFANARU, C., MCARTHUR, A. \& AROMATARIS, E. 2018. Systematic review or scoping review? Guidance for authors when choosing between a systematic or scoping review approach. BMC Medical Research Methodology, 18(1), p.143. https://doi.org/10.1186/ s12874-018-0611-X

MYERS, S.S., GAFFIKIN, L., GOLDEN, C.D., OSTFELD, R.S, REDFORD, K.H, RICKETTS, T.H. et al. 2013. Human health impacts of ecosystem alteration. Proceedings of the National Academy of Sciences, 110(47), pp.1875318760. https://doi.org/10.1073/ pnas.1218656110
NEL, J.L., LE MAITRE, D.C., ROUX, D.J., COLVIN, C., SMITH, J.S., SMITHADAO, L.B. et al. 2017. Strategic water source areas for urban water security: Making the connection between protecting ecosystems and benefiting from their services. Ecosystem Services, 28, pp. 251-259. https://doi. org/10.1016/j.ecoser.2017.07.013

NIEUWOUDT, H., GRUNDLING, P.L., DU TOIT, L. \& TERERAI, F. 2018.

Pietersieliekloof wetland rehabilitation project - Investing in the future: Wetland rehabilitaion. Water Wheel, 17(2), pp. 26-28.

NTSALUBA, G. 2014. KwaZuluNatal water crisis: Too little too late. Corruption Watch. [Online]. Available at: <https://www.corruptionwatch.org. za/kzn-water-crisis-too-little-too-late/> [Accessed: 27 March 2014].

NYAM, Y.S., KOTIR, J.H., JORDAAN, A.J., OGUNDEJI, A.A. \& TURTON, A.R. 2020. Drivers of change in sustainable water management and agricultural development in South Africa: A participatory approach. Sustainable Water Resources Management, 6(4), pp.1-20. https://doi.org/10.1007/ s40899-020-00420-9

OXFAM. 2010. Climate change, development and energy problems in South Africa: Another world is possible. Melbourne, Australia: Earthlife Africa \& Oxfam International.

PAPADOURIS, A. \& THOPIL, G.A. 2018. Scenario analysis of renewable energy desalination integration in South Africa. In: Proceedings of the International Conference on Industrial Engineering and Operations Management, 29 October-1 November, Pretoria, South Africa, pp. 1767-1780.

PATRICK, H.O. 2019. Climate change and water security in South Africa: Assessing conflict and coping strategies in KwaZulu-Natal province. Unpublished PhD. thesis. Department of Political Science, University of KwaZulu-Natal, Durban, South Africa.

PATRICK, H.O. 2020. Climate change, water security, and conflict potentials in South Africa: Assessing conflict and coping strategies in rural South Africa. In: Filho, W.L., Luetz, J. \& Ayal, D. (Eds). Handbook of climate change management. Cham, Switzerland: Springer, pp.1-18. https://doi. org/10.1007/978-3-030-22759-3_84-1
PHAROACH, R., HOLLOWAY, A.J. FORTUNE, G., CHAPMAN, A., ZWEIG, P. \& SCHABER, E. 2016. Off the radarsynthesis report: High impact weather events in the Western Cape, South Africa. Research Alliance for Disaster and Risk Reduction (RADAR).

POWERS, J.G., KLEMP, J.B., SKAMAROCK, W.C., DAVIS, C.A., DUDHIA, J., GILL, D.O. et al. 2017. The weather research and forecasting model: Overview, system efforts, and future directions. Bulletin of the American Meteorological Society, 98(8), pp. 1717-1737. https://doi. org/10.1175/BAMS-D-15-00308.1

RODINA, L. 2019. Planning for water resilience: Competing agendas among Cape Town's planners and water managers. Environmental Science \& Policy, 99, pp. 10-16. https://doi. org/10.1016/j.envsci.2019.05.016

ROHR, H., CILLIERS, J. \& FOURIE, W. 2017. Spatial planning and land-use management tools in aid of securing water sustainability: The case study of Mogalakwena Local Municipality in South Africa. Town and Regional Planning. 71(1), pp.11-23. https://doi. org/10.18820/2415-0495/trp71i1.2

SAHRC (SOUTH AFRICA HUMAN RIGHTS COMMISSION). 2014. Report on the right to access sufficient water and decent sanitation in South Africa. South Africa Human Rights Commission.

SAUL, J.S. \& BOND, P. 2014. South Africa - The present as history: From Mrs Ples to Mandela and Marikana. New York, USA: Boydell and Brewer Ltd.

SCHEWE, J., HEINKE, J., GERTEN, D., HADDELAND, I., ARNELL, N., CLARK, D. et al. 2014. Multimodel assessment of water scarcity under climate change. Proceedings of the National Academy of Sciences, 111(9), pp. 3245-3250. https://doi.org/10.1073/ pnas. 1222460110

\section{STATS SA (STATISTICS SOUTH}

AFRICA). 2014. Annual report. [Online]. Available at: <www.statssa.gov.za.> [Accessed: 20 April 2020].

THEISEN, O., GLEDITSCH, N. \& BUHAUG, H. 2013. Is climate change a driver of armed conflict? Climate Change, 117(3), pp. 613-625. https:// doi.org/10.1007/s10584-012-0649-4 
TURPIE, J. \& VISSER, M. 2013. The impact of climate change on South Africa's rural areas. In: Financial and fiscal commission (ed.). Submission for 2013/2014. Division of Revenue. Johannesburg, South Africa, RP: $148 / 2012$, pp. $65-72$.

\section{UNFCCC (UNITED NATIONS FRAMEWORK CONVENTION ON CLIMATE CHANGE). 2011. Fact} sheet: Climate change - The status of climate change science today. [Online]. Available at: <https://unfccc.int/files/ press/backgrounders/application/pdf/ press_factsh_science.pdf.> [Accessed: 20 April 2020].

\section{UN-WATER (UNITED NATIONS} WATER). 2013. Water security and the global water agenda. Hamilton, Ontario, Canada: United Nations University, Institute for Water, Environment \& Health.

\section{UNITED STATES GEOLOGICAL}

SURVEY. nd. Where is earth's water? U.S. Department of the Interior. [Online]. Available at: <https://www. usgs.gov/special-topic/water-scienceschool/science/where-earths-water?qtscience_center_objects $=0$ \#qt-science center_objects>. [Accessed: 13 June 2020].

VINCENT, K., CULL, T., CHANIKA, D., HAMAZAKAZA, P., JOUBERT, A., MACOME, E. et al. 2013. Farmers' responses to climate variability and change in Southern Africa - Is it coping or adaptation? Climate and Development, 5(3), pp.194-205. https:// doi.org/10.1080/17565529.2013.8210 52

VON-BORMANN, T. 2014.

Understanding the food energy water nexus: Through the water and food lens. Cape Town, South Africa: Worldwide Fund for Nature.

VON-BORMANN, T. \& GULATI, M. 2014. Understanding South Africa's most urgent sustainability challenge. Cape Town, South Africa: Worldwide Fund for Nature.

WILK, J., ANDERSSON, L. \& WARBURTON, M. 2013. Adaptation to climate change and other stressors among commercial and small-scale South African farmers. Regional Environmental Change, 13(2), pp. 273-286. https://doi.org/10.1007/ s10113-012-0323-4
WORLD BANK. 2014. Water resources management: Sector result profile. The World Bank Group. [Online]. Available at: <https://www.worldbank. org/en/results/2013/04/15/waterresources-management-results-profile> [Accessed: 20 April 2020].

XIA, J., DUAN, Q.Y., LUO, Y., XIE, Z.H., LIU, Z.Y. \& MO, X.G. 2017. Climate change and water resources: Case study of Eastern Monsoon Region of China. Advances in Climate Change Research, 8(2), pp. 63-67. https://doi. org/10.1016/j.accre.2017.03.007

ZADAWA, A.N. \& OMRAN, A.

2018. Climate change and water security issues in Africa: Introducing partnership procurement for sustainable water projects in Nigeria. In: Omran, A. \& Schwarz-Herion, O. (Eds). The impact of climate change on our life. Singapore: Springer, pp.127-134. https://doi. org/10.1007/978-981-10-7748-7_6

ZHENG, Y. \& BYG, A. 2014. Coping with climate change: Households' response strategies to drought and hailstorm in Lijiang, China. Environmental Hazards, 13(3), pp. 211-228. https://doi.org/10.1080/17477 891.2014.902799

ZHU, T. \& RINGLER, C. 2010. Climate change implications for water resources in the Limpopo River Basin (No. 961). International Food Policy Research Institute (IFPRI).

\section{ZHUWAKINYU, M. 2012. Water} 2012. A review of South Africa's water sector. Report. Creamer Research. Johannesburg, South Africa.

ZIERVOGEL, G., SHALE, M. \& DU, M. 2010. Climate change adaptation in a developing country context: The case of urban water supply in Cape Town. Climate and Development, 2(2), pp. 94-110. https://doi.org/10.3763/ cdev.2010.0036

\section{ZIERVOGEL, G., NEW, M., ARCHER} VAN GARDEREN, E., MIDGLEY, G., TAYLOR, A., HAMANN, R. et al. 2014. The impact of climate change and adaptation in South Africa. Wiley Interdisciplinary Reviews: Climate Change, 5(5), pp. 605-620. https://doi. org/10.1002/wcc.295
ZUBAIDI, S.L, ORTEGA-MARTORELL, S., AL-BUGHARBEE, H., OLIER, I., HASHIM, K.S., GHARGHAN, S.K. et al. 2020. Urban water demand prediction for a city that suffers from climate change and population growth: Gauteng province case study. Water, 12(7), p. 1885. https://doi.org/10.3390/ w12071885 